\title{
Needs Analysis in Learning History Model of Senior High School
}

\author{
Nur Ahyani \\ Faculty of Education \\ Universitas Negeri Surakarta \\ Solo, Indonesia \\ nurahyani63@gmail.com
}

\author{
Soetarno Joyoatmojo, M. Ahyar, Nunuk Suryani \\ Faculty of Education \\ Universitas Negeri Surakarta \\ Solo, Indonesia
}

\begin{abstract}
The purpose of this study was to determine the condition of learning the history of high school in the city of Palembang and the needs of the learning model history. This is a qualitative research, research strategy that is used is single-embedded. Research conducted at the high school in Palembang City, namely SMA 22, SMA 14, SMA 13, SMA 21 and SMA PGRI 2. Sources of research data consisted of informants and documents. Data collection techniques used were interviews, observation and document analysis. The validity of the source data using triangulation techniques and triangulation methods. Data analysis technique that is used is the technique of interactive analysis. The result showed that in general the history teachers in Palembang as the samples when implementing the learning process is already making preparations such as syllabus and lesson plans, but not many teachers use instructional model although listing them in the RPP. In the process of learning in general, teachers use the lecture method varied with cognitive assessment. The conclusion of this study is the need for the development of a model of teaching history can enable students and accommodate all the potential of the students.
\end{abstract}

\section{Keywords-Learning Model, History}

\section{INTRODUCTION}

One of the aims of history teaching in the curriculum in 2013 is to raise awareness in self-learners as part of the Indonesian people who have a sense of pride and patriotism, gave birth to empathy and tolerant behavior that can be implemented in various areas of public life. [1]

Conditions of teaching history at school level is still a concern, this is reinforced by the many research results reveal that there are shortcomings in the teaching of history. History teaching in the classroom showed weaknesses such as lack of diversity in teaching methods and learning is konservatif ${ }^{8}$. The history teacher is not a lot that connects the subject matter of history with the values contained in learning materials sejarah. [2] Learning history is less desirable students, as it is considered a boring lesson and unpleasant ${ }^{5}$. Other causes of students' lack of interest towards learning history is a teacher rarely use instructional media. [3]
Associated with the condition of high school history teaching in the field, it is necessary to study and practice the mastery of learning models for history teachers. Teaching models developed ideally could increase interest in learning, growing a sense of history, feel the benefits of studying history, and accommodate all the potential of learners. [4]

History in the learning process, the development potential of learning must be done thoroughly and integrated (holistic). Development of potential learners are not balanced consequences of education tend to be more concerned with development of one aspect only and partial. Teacher plays a strategic role, especially in order to form the national character through the development of personality and values as desired. In the case, the history teacher in the learning process did not enough only armed with the knowledge related to the subject they teach, but needs to pay attention to aspects of holistic learning that support the realization of the development potential of learners. [5] So, history teacher in the learning process not only act as a transmitter of knowledge (transfer of knowledge) but also acts as a transmitter of values (transfer of values).

Based on conditions the process of teaching history, the researchers conducted research on the needs analysis model of learning history. This research is to see how the learning process that takes place in school history, and needs a learning model that history teachers needed to tackle the problems they face teaching history.

This study is expected to be the solution to the problems of teaching history in high school, so that through the appropriate model of teaching history, history teaching into learning fun, interesting, students become active, and the potential possessed learners can be developed as a whole. [6] Likewise, the potential of the students can develop in a balanced manner. [7] This is consistent with the idea that the learning model is a framework of thinking that is used as a guide for implementing the learning activities in order to achieve the learning objective. [8] One alternative model of learning history is a holistic learning model.[9]

\section{RESEARCH METHODOLOGY}

This research is the development, on a preliminary study is qualitative research. Research conducted at SMA 13, SMA 21, SMA 22, SMA 15 and SMA PGRI 2 Palembang. The research was conducted in the second semester of 2014. The sample consists of history teachers and students, the 
number of students as the samples 119 students and teachers of 5 people. Data were collected through observation, interviews with teachers (informant), questionnaires and document analysis (RPP, and syllabus). The validity of the data using triangulation techniques and triangulation method. The source of data analysis was using the technique of interactive analysis ${ }^{16}$. This model consist of three components of the analysis are linked to one another simultaneously, namely: (a) the reduction of the data; (b) the presentation of the data; and (c) conclusion (verification). Activities conducted with interactive forms with process flow (cycle).

\section{RESEARCH RESULT}

The result of questionnaire distributed to students are able be seen in table I.

\section{TABLE 1: RESPONSES OF STUDENTS TO} TEACHERS IN LEARNING

\begin{tabular}{|c|c|c|c|}
\hline No. & Statement & $\begin{array}{l}\text { Percentage } \\
(\%)\end{array}$ & Information \\
\hline 1 & $\begin{array}{l}\text { The response to the } \\
\text { subjects of history }\end{array}$ & 52,94 & $\begin{array}{l}\text { Do not like a } \\
\text { history lesson }\end{array}$ \\
\hline 2 & $\begin{array}{l}\text { The response to the } \\
\text { learning process of } \\
\text { history }\end{array}$ & 52,10 & Not fun \\
\hline 3 & $\begin{array}{l}\text { Variations in the use } \\
\text { of methods }\end{array}$ & 63,03 & $\begin{array}{l}\text { Rarely change } \\
\text { method }\end{array}$ \\
\hline 4 & $\begin{array}{l}\text { The method used by } \\
\text { the teacher }\end{array}$ & 42,03 & $\begin{array}{ll}\text { Lecture, } & \text { question } \\
\text { and } & \text { answer, } \\
\text { discussion, } & \\
\text { assignment } & \\
\end{array}$ \\
\hline 5 & $\begin{array}{l}\text { Use of Learning } \\
\text { Model }\end{array}$ & 47,89 & Rarely using model \\
\hline 6 & $\begin{array}{l}\text { Linking lessons with } \\
\text { values (affective) }\end{array}$ & 43,96 & $\begin{array}{l}\text { Rarely connect the } \\
\text { lesson with values }\end{array}$ \\
\hline 7 & $\begin{array}{l}\text { Sampling of the } \\
\text { attitude from the } \\
\text { historical material }\end{array}$ & 51,26 & Rarely carry out \\
\hline 8 & $\begin{array}{l}\text { Giving freedom to } \\
\text { hold opinions }\end{array}$ & 56,20 & $\begin{array}{ll}\text { Rarely provides an } \\
\text { opportunity } \\
\text { argues }\end{array}$ \\
\hline 9 & $\begin{array}{l}\text { Provide an } \\
\text { opportunity to discuss }\end{array}$ & 46,21 & $\begin{array}{ll}\text { Often provide an } \\
\text { opportunity } & \text { to } \\
\text { discuss } & \\
\end{array}$ \\
\hline 10 & $\begin{array}{l}\text { Gives the opportunity } \\
\text { to use other learning } \\
\text { resources }\end{array}$ & 47,05 & $\begin{array}{l}\text { Rarely give a } \\
\text { chance to find the } \\
\text { source of learning } \\
\text { another }\end{array}$ \\
\hline
\end{tabular}

Based on the table above it can be seen that most of the students $(52,94 \%)$ did not like the subjects of history. In response to the process of teaching history, most of the students $(52,10 \%)$ stated that the learning process that was delivered the teachers not pleasant. Most of the students $(63,03 \%)$ stated that teachers rarely change in teaching methods. Most of the students $(42,03 \%)$ stated that teachers in teaching always use the lecture method, question and answer, discussion, and assignments. The use of model of learning by teachers classified as rare, as expressed by most of the students $(47,89 \%)$. In the process of learning, teachers rarely connect lesson material with the values that are affective, as disclosed most of the students $(43,96 \%)$. Furthermore, teachers rarely take the example of the attitude from the subjects of history; this is revealed most of the students $(51,26 \%)$. According to most of the students $(56,20 \%)$ teachers rarely provides the opportunity for students to express their opinions. Most students $(46,21 \%)$ state that teachers often give students the opportunity to discuss. In the use of learning resources, according to the student $(47,05 \%)$ teachers rarely give students the opportunity to look for other learning resources.

Result of interviews conducted with 5 teachers of history obtained the following results. In principle, the learning can be divided into three parts, namely (1) lesson plan (RPP), the implementation of learning, and (3) assessment. The description of each section is as follows.

Based on an interviews with Mr. Joko Edi Purwanto, SMAN 21 Palembang, June 11, 2014, Ms. Handayani, SMA Negeri 22 Palembang, and Ms. Zainab, SMAN 13 Palembang, June 16 2014, that a teacher of history in general at the time will be implementing learning always prepare lesson plans that refers to Permendikbud No. 65 Year 2013 on the Standard Process Primary and Secondary Education.

Based on observations and interviews with the Principal, Vice Principal of Curriculum and History teacher about the implementation of learning in high school History Palembang City, a picture that generally the teachers in implementing the learning process has been implemented in accordance with the order of the lesson plans. In the learning process teachers use learning model is quite diverse, it is expressed by Ms. Srikandi from SMA Negeri 15 Palembang, disclosed that the history teacher in the learning process using the learning model as the model Role Playing, Talking stick, STAD, jigsaw, and still many other models that have been used. (Interview with Mrs. Srikandi, MM on June 21, 2014). Added by mother Srikandi that for history courses, the teacher is in conformity with the educational background, namely from historical education.

Implementation of the assessment in the learning process, in general, high school history teachers in Palembang is still focused on the cognitive, affective and psychomotor not been fully implemented. It is based on interviews conducted with Mrs. Srikandi from SMA 15 and Mr. Sultan Sahrir from SMA PGRI 2 Palembang (13 and 15 August 2014) stating that during this time in assessing students from his judgment likely to form the cognitive is to ask about matters relating to given the subject matter. $\mathrm{He}$ explained that because lesson material is very dense history, so that on one hand the students should master the material with the allocation of time specified in the syllabus.

In an effort to improve the quality of Teaching History, various efforts have been carried out by teachers of history such ass table II. 
Table II. EFFORT THAT HISTORY TEACHER DO TO IMPROVE THE QUALITY OF EDUCATION

\begin{tabular}{|l|l|c|c|c|c|}
\hline \multirow{2}{*}{ No. } & \multicolumn{1}{|c|}{ Statement } & \multicolumn{4}{|c|}{ Answer Options } \\
\cline { 3 - 6 } & \multicolumn{1}{|c|}{ SL } & SR & JR & TP \\
\hline 1. & $\begin{array}{l}\text { Improving the quality of } \\
\text { Preparation lesson plans }\end{array}$ & 20 & 3 & & \\
\hline 2. & $\begin{array}{l}\text { Contextual learning } \\
\text { materials cultivated }\end{array}$ & 18 & 5 & & \\
\hline 3. & $\begin{array}{l}\text { Improved classroom } \\
\text { management }\end{array}$ & 23 & & & \\
\hline 4. & $\begin{array}{l}\text { Involvement of students in } \\
\text { the learning process }\end{array}$ & 23 & & & \\
\hline 5. & $\begin{array}{l}\text { Application of teaching } \\
\text { models }\end{array}$ & 15 & 8 & & \\
\hline 6. & $\begin{array}{l}\text { The use of diverse learning } \\
\text { resources }\end{array}$ & 18 & 5 & & \\
\hline 7. & $\begin{array}{l}\text { The use of instructional } \\
\text { media }\end{array}$ & 23 & & & \\
\hline 8. & $\begin{array}{l}\text { Improving learning } \\
\text { assessment system }\end{array}$ & 19 & 4 & & \\
\hline 9. & $\begin{array}{l}\text { Result of the assessment to } \\
\text { reflect the learning }\end{array}$ & 16 & 7 & & \\
\hline
\end{tabular}

Based on the result of the questionnaire can be seen that the history teachers in Palembang are trying to improve the learning of History. Such as creating lesson plans, using contextual learning, classroom management, student engagement in the learning process, the application of learning models, use a variety of learning resources, the use of media learning and improve learning assessment system.

\section{DISCUSSION}

The lesson of history less attractive to students in learning can be caused by several things, including the result of the questionnaire stated, teachers rarely use the learning model. The learning model is very important to be understood and applied by teachers in teaching because as a conceptual framework that describes a systematic procedure ${ }^{15}$. Teacher in the learning process did not use the learning model, implementation will not be effective because the teacher does not focus the learning steps which organized the material. It consequences the learning did not work effectively, one of them is students are less interested in the learning ${ }^{10}$. Based on interviews and questionnaire state that, teachers in teaching already using learning models, but its implementation is not in accordance with the lesson plans. The learning model is written in lesson plans has not fully practiced in learning, this is due to a lack of understanding of teachers to the learning model that will be used.

Another cause from a lack of interest of students to the lesson of history is that teachers are often only reveal the historical facts that are memorizing and tend to concerned with students' cognitive and ignore the realm and attitudes. The teaching of history is not just memorizing the facts of history or historical periodization, but more important is making the values from the events in the past. [10] Result were not in line with the result of the questionnaire stating that the history teacher rarely take the values from past historical events in the learning process, it is what ties of history teaching less attractive and monotonous. [11]

Based on this research, the teacher in the learning process of history rarely give students the chance to argue. This causes students to think critically about history teaching. [12] In the use of learning resources, teachers rarely give students the opportunity to look for other learning resources. This resulted in the insight and knowledge of students is less developed. [13]

Based on interviews and questionnaires given to 23 teachers, the work done history teachers are (1) amounted to $86 \%$ of teachers trying to improve the quality of manufacture of the lesson plan; (2) amounted to $78 \%$ of teachers trying to convey with contextual learning materials; (3) $100 \%$ of teachers to improve the quality of classroom management (4) $100 \%$ of teachers engage students in the learning process (5) $65 \%$ of teachers applying the learning model; (6) $78 \%$ of teachers use a variety of learning resources; (7) $100 \%$ of teachers use pemeblajaran media; (8) $82 \%$ of the teachers improve learning assessment system; and (9) 69\% of teachers use assessment as a reflection of learning. Numerous attempts made history teachers, the use of the learning model showing the lowest percentage at $65 \%$. That condition requires a solution, among others, by the provision of a variety of learning models of training, fun students, and accommodate all potential students (cognitive, affective, and psychomotor) to teachers ofhistory. [14]

As one pole or the main foundation for social studies education (history) mainly for the cultivation of values such as identity, empathy, tolerance, the necessary learning model that can accommodate these objectives. [15]

\section{CONCLUSION}

Based on the result of research and discussion can be concluded that the condition of history teaching high school in Palembang city is quite nice, but the need for improvements in the delivery of learning materials mainly by using model. By using a learning model, all components become systematic learning, starting from organizing materials, methods, media learning resources and assessment. From the findings of the preliminary study, hence the need for the development a model student learning that can be fun, and accommodating all students' potential (cognitive, affective, and psychomotor.

\section{ACKNOWLEDGEMENT}

Researchers deliver to many thanks to the school (SMA) in Palembang, Promotor from University (UNS), the Government (Higher Education) and all those who helped in the implementation of this study. 


\section{REFERENCES}

[1] Kemendikbud. (2013). Sejarah Indonesia (Buku Guru). Jakarta: Kementrian Pendidikan dan Kebudayaan. Jakarta: Kemendikbud

[2] Akinoglu, O. (2005). History Education and Identity. International Journal of Historical Learning, Teaching and Research. Vol. 2, No. 1; 2005.234-242.

[3] Gestdottir, S.M. (2013). The Challenges of History Education in Iceland. International Journal of Historical Learning, Teaching and Research. Vol. 11.2; 98- 110.

[4] Tirri, K. (2011). Holistic School Pedagogy and Value: Finnish Teachers and Students Perspective. International Journal of Education Research. 50 (2011) 159-165.

[5] Sultana, N. (2010). Promoting Social Skills and Character Building Through Classroom Instruction. Journal of The Humanities. Vol. 6. No. 2; 152-162.

[6] Miller, J.P., Selia, K., Diana, D., Deborah O., Isabella, C.K. (2005). Holistic Learning And Spirituality in Education. Breaking New Ground. Albany: State University of New York Press.

[7] Sagala, Syaiful. (2009). Kemampuan Profesional Guru dan Tenaga Kependidikan. Bandung: Alfabeta.

[8] Anitah, S. (2009). Teknologi Pembelajaran. Surakarta: UNS Press

[9] Jafari, E., Nasrabadi, H.A., dan Liaghatdar, M.J. (2012). Holistic Education: An Apprroach for 21 Century. International Education Studies. Vol.5, No. 2. April 2012

[10] Brett, P. (2005). Citizenship Through History-Whats Is Good Practice. International Journal of Historical, Learning, Teaching and Research. Vol. 2, No. 3; 132-141.

[11] Wiraatmadja, R. (2002). Pendidikan Sejarah di Indonesia. Bandung: Historia Utama Press.
[12] Zuhairi, A. (2006). "The Historical Context, Current Development, and Future Challenges of Distance Education in Indonesia". The Quarterly Review of Distance Education. Vol.7 (1), 95-10

[13] Audigier, F. (2005). Pupils' Conception of History and History Teaching. International Journal of Historical Learning, Teahing and Research. Vol. 5, Number 1, Januari 2005.

[14] Honing, T., Claessens, W., \& Admiral, W (2012). Effects of The Use of Concept Maps on Historical Overview Knowledge. International Journal of Historical Learning, Teaching and Research. Vol. 11. No. 1; 94-105.

[15] Widja, I.G. (2002) Menuju Wajah Baru Pembelajaran Sejarah. Yogyakarta: Lappera Pustaka Utama. 